\title{
Pengenalan Budaya Membaca pada Anak Usia Dini melalui Media Permainan Kartu
}

\author{
Faizatul Widat ${ }^{\natural}{ }^{\bowtie}$, Habib Anwar Al Anshoriं ${ }^{2}$, Amir ${ }^{3}$, Nurul Istiqamah1, Litfiyati1 $^{1}$ \\ Pendidikan Anak Usia Dini, Universitas Nurul Jadid, Paiton, Probolinggo, Indonesia(1) \\ Pandidikan Agama Islam, Universitas Islam egeri Sultan Aji Muhammad Idris Samarinda, \\ Indonesia(2) \\ Universitas Islam Negeri Kiai Haji Achmad Siddiq Jember, Indonesia(3) \\ DOI: $\underline{10.31004 / o b s e s i . v 6 i 4.2028}$
}

\begin{abstract}
Abstrak
Budaya membaca bagi anak sangat dibutuhkan, khususnya dalam rangka menumbuh kembangkan potensi mereka sesuai dengan harapan semua pihak. Oleh karena itu, diperlukan media yang tepat guna dalam mengenalkan budaya membaca kepada anak. Penelitian ini bertujuan untuk mengkaji tentang bagaimana mengenalkan RA Masyitoh IX Sumberejo Paiton Probolinggo. Penelitian ini menggunakan pendekatan kulitatif jenis studi kasus. Teknik analisis data berupa reduksi data, display data, dan gambaran atau kesimpulan. Hasil penelitian menunjukkan bahwa; pertama, lembaga RA Masyitoh IX menggunakan media permainan kartu huruf dalam mengenalkan anak didik pada budaya pramembaca, kedua presentation dilakukan dengan cara preparing the program, pre-reading card presentation, asesment pramembaca. Implikasi yang diperoleh dalam pengenalan budaya pramembaca melalui permainan kartu angka anak didik mampu mengembangkan pemahaman membaca awal serta mampu menjadi daya tarik untuk anak didik dalam melakukan permainan kartu huruf guna pengenalan pramembaca.
\end{abstract}

Kata Kunci: budaya membaca; media; permainan kartu

\begin{abstract}
Reading culture for children is very much needed, significantly to develop their potential by the expectations of all parties. Therefore, appropriate media are needed in introducing reading culture to children. This study examines how to introduce RA Masyitoh IX Sumberejo Paiton Probolinggo. This research uses a case study type qualitative approach. Data analysis techniques are data reduction, data display, and an overview or conclusion. The results showed that the RA Masyitoh IX institution uses letter card game media to introduce students to pre-reading culture. Secondly, the presentation is done by preparing the program, prereading card presentation, and pre-reading assessment. The implications obtained in the introduction of pre-reading culture through number card games are that students can develop early reading comprehension and become an attraction for students to play letter card games for pre-reading recognition.
\end{abstract}

Keywords: Reading Culture, Media, Card Games

Copyright (c) 2022 Faizatul Widat, et al.

$\triangle$ Corresponding author:

Email Address : faizatulwidat59@gmail.com (Probolinggo Jawa Timur, Indonesia)

Received 29 September 2021, Accepted 21 December 2021, Published 24 January 2022 


\section{PENDAHULUAN}

Masa kritis pada pembangunan manusia terjadi pada masa anak usia dini, dan pada saat ini pula memerlukan suatu pendidikan yang menjadi sentral mendasar sebagai sebuah strategi dalam membangun sumberdaya manusia (Yunia, 2016). Proses pendidikan terhadap anak usia dini yakni pemberian pembinaan yang dilakukan semenjak lahir sampai kurun usia enam tahun, ini dilakukan dengan cara stimulant atau rangsangan yang dapat menumbuhkan perkembangan rohani maupun jasmani shingga memiliki kesiapan lanjutan (Lasaiba, 2016).

Pada faktanya setiap individu tidak sama, mereka mempunyai ciri khas sendiri hal ini bukan hanya dari perspektif fisik maupun psikis (Ahour \& Haradasht, 2014). Pada tingkat kecerdasan anak juga memiliki perbedaan dari anak satu dengan yang lainnya sangat berbeda (Br \& Asiya, 2021), sebab anak memiliki ciri yang unik (Iltiqoiyah, 2020). Dalam hal ini proses pembelajaran yang baik dan tepat akan mampu mempengaruhi kualitas pembelajarannya (Selian, 2019; Finori, 2019). Sebab itu menjadi tuntutan bagi guru harus mempunyai pengetahuan kreatif dan inovatif supaya proses pembelajaran dapat tercapai secara optimal (Kristin, 2018; Aryani et al., 2021).

Kegiatan belajar mengajar yang menarik dapat digunakan dalam mengembangkan kemampuan anak, hal ini bisa dilakukan dengan pola kegiatan pembelajaran yang berpusat pada anak dengan memberikan kepercayaan penuh terhadap anak sehingga anak berkesempatan belajar secara langasung pada kegiatan pembelajaran tersebut (Fardiah et al,. 2019; Alfina \& Anwar, 2020). Kegiatan pembelajaran yang berpusat pada minat anak akan lebih positif daya tangkapnya dari pada pembelajaran yang berpusat pada guru, jadi guru bisa menggunakan bantuan media untuk mengarahkan pada kegiatan pembelajaran yang bermakna (Retnaningrum, 2016; Pusvitasari, 2021; Wahyudin et al., 2021).

Tuntutan untuk para tenaga pendidik baik dari luar pendidikan maupun dari dalam pendidikan yakni seorang anak bisa dikatakan berhasil jika sudah mampu membaca dan menulis (Rizqiyah, 2020), sedangkan baca tulis pada pendidikan anak usia dini tidak diperkenankan sebab melihat faktor usia mereka yang masih dini. Padahal baca tulis merupakan hal yang perlu dibiasakan pada anak sebab dengan pengenalan pramembaca awal mampu mempersiapkan keterampilan membaca anak sebelum memasuki sekolah selanjutnya (Umiarso et al., 2022). Sebagaimana disampaikan oleh peneliti terdahulu diantaranya; Pertiwi (2016) pramembaca kemampuan bahasa reseptif yang dilalui anak usia dini dalam upaya menyiapkan pemahaman membaca sebelum masuk pada sekolah selanjutnya. Kemudian Fitriya (2014) pramembaca atau membaca permulaan yakni tahap pembelajaran awal membaca yang akan menjadi podasi pada tahap pembelajaran membaca selanjutnya yang dilakukan pada kelas tinggi.

Kemampuan membaca menjadi hal yang penting bagi perkembangan akademik anak dan harus dimiliki oleh semua siswa (Simanjuntak et al., 2020). Selanjutnya Eka (2014) pramembaca atau membaca dini dipelajarai secara terprogram yang dilakukan pada anak prasekolah. Perantara bisa menggunakan melalui media atau permainan agar lebih menarik untuk diikuti. Istilah "melek huruf" muncul dalam literatur khusus pada akhir tahun sembilan puluhan abad terakhir. Pada tingkat yang paling umum, ini mencakup keterampilan dan kemampuan untuk menggunakan keterampilan yang diperoleh (misalnya membaca dan menulis) (Wildova \& Kropackova, 2015).

Fakta di lapangan khususnya RA Masyitoh IX Sumberejo Paiton Probolinggo terkait dengan pramembaca yaitu; adanya tuntutan dari pihak wali murid serta jenjang pendidikan yang selanjutnya yang mengahruskan anak mampu baca tulis, sedangnkan keadaan dilapangan anak belum mampu mengenal huruf, anak belum mampu mengeja kata sederhana, anak belum terampil menulis serta anak kurang konsentrasi ketika guru mengenalkan pramembaca awal. Hal ini disebabkan kurangnya inovasi guru dalam menggabungkan pembelajaran dengan media yang tepat guna dalam memancing anak lebih tertarik mengikuti pembelajaran yang dipandu oleh guru (Munawar, 2019; Babuta \& Rahmat, 2019; Putri \& Surya Abadi, 2021). 
Fenomena tersebut memberikan gairah pada para tenaga pendidik agar selalu berinovasi dalam menciptakan dunia pendidikan yang menyenangkan namun bisa memenuhi target yang diharapkan oleh lingkungan, dalam memenuhi tuntutan lingkungan guru harus mampu berinovasi dalam mengenalkan membaca tanpa harus dengan cara paksa membaca.

Dalam mengintegrasikan pengenalan budaya pramembaca pada anak RA Masyitoh IX Sumberejo Paiton Probolinggo mangadopsi terobosan baru dengan bantuan sebuah media. Sebab media mampu memberikan stimulasi tepat dan optimal dalam menumbuh kembangkan kemampuan anak. Media yang dipilih pada RA Masyitoh IX Sumberejo Paiton Probolinggo dalam mengenalkan budaya pramembaca awal yakni dengan menggunakan bantuan metode pembelajaran permainan kartu. Media ini meski dengan cara sederhana dikenal mampu mengarahkan anak pada proses pembelajaran yang lebih bermakna (Retnaningrum, 2016; Dakir, 2017). Akhmad Shunhaji, (2020) mengatakan bahwa sebuah media atau alat permainan edukatif merupakan media yang dibuat khusus sebagai alat bantu mengajar serta mampu mengoptimalkan perkembangan yang dimiliki anak. Meningkatkan kemampuan bahasa dan pemahaman pada anak usia dini dapat menggunakan media (Laila \& Candraloka, 2019)

Dalam menyiapkan kemampuan membaca seorang anak, sebelum masuk pada jenjang pendidikan selanjutnya, proses pramembaca distimulan pada anak disesuaikan melalui tahapan yang tepat misal pengenalan huruf vokal dan konsonan, mengeja gabungan huruf, kemudian dilanjutkan pada tahap menulis. Untuk menghadapi kasus ini peneliti memfokuskan pada proses belajar mengajar dengan mengenalkan anak pada budaya pramembaca awal melalui bantuan metode pembelajaran permainan media kartu.

Banyak penelitian tentang media kartu yang dapat memotivasi pramembaca anak yang dilakukan oleh para peneliti, di antaranya; Rahmat \& Heryani, (2014) menyampaikan media kartu gambar bisa meningkatkan daya ingat anak dalam menguasi kosa kata. Selanjutnya Asmonah, (2019) mengatakan kegiatan pramembaca berbantuan media kartu kata yang bergambar yakni kegiatan pembelajaran langsung untuk penguasaan pengetahuan prosedural maupun keterampilan. Media Kartu kata memiliki tujuan memikat para pembaca, sebab pada media kartu terdapat bermacam warna sehinga menarik perhatian anak didik (Rumidjan, Sumanto, \& Badawi, 2017). Selanjutnya Hidayati, YP, \& Artharina (2019) mengatakan model permainan berbantuan media gambar mampu meningkatkan kemampuan membaca serta kempauan bersosial.

Uraian dari sejumlah peneliti tersebut menjelaskan tentang pentingnya metode pembelajaran permaianan kartu dalam mengenalkan budaya pramembaca pada anak usia dini. Merujuk dari uraian tersebut maka peneliti memiliki ketertarikan untuk mengkaji kembali mengenai pengenalan pramembaca anak yang menggunakan bantuan pertamianan kartu dalam menumnuhkan minat serta ketertarikan anak pada budaya membaca sejak dini. Penelitian ini diharapkan dapat memberikan kontribusi terhadap strategi yang harus dilakukan oleh guru dalam memperkuat aspek literasi anak sejak usia dini melalui permainan kartu.

\section{METODOLOGI}

Pada penelitian ini menggunakan pendekatan kualitatif jenis studi kasus dengan melakukan penelitian yang bermaksud untuk menggambarkan masalah serta melakukan Analisa terhadap permasalahan yang terjadi. Tempat penelitian pada lembaga jenjang raudlatul athfal yakni, RA Masyitoh IX Sumberejo Paiton Probolinggo.

Peneliti mengumpulkan data melalui beberapa tahap seperti; pengamatan, mengamati langsung pada tempat penelitian. Wawancara, mewawancarai sejumlah informan yang ada ditempat penelitian. Observasi, melakukan kunjungan pada tempat penelitian. Study dokumentasi, menganalisa dokumen-dokumen yang berkaitan dengan penelitian. 
Sumber informasi pada penelitian ini melalui interview terhadap kepala sekolah, guru serta wali murid RA Masyitoh IX. Sumber data collection data, analisis berbentuk reduksi, display data kemudian gambaran kesimpulan. Pada tahap awal pengumpulan data, selanjutnya reduksi data yang dipilah dalam bentuk catatan, kemudian display data memahami tetang data tersebut yang kemudian dilakukan penarikan kesimpulan dari data yang diteliti.

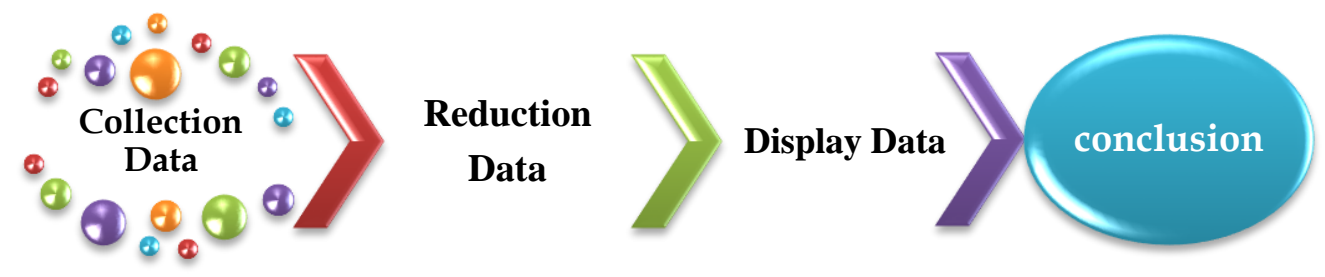

Gambar 1. Proses Pengumpulan Data (Milles \& Huberman, 2014)

\section{HASIL DAN PEMBAHASAN}

Hasil penelitian menunjukkan bahwa; metode pembelajaran permaianan kartu dalam mengenalkan budaya pramembaca pada anak usia dini di RA Masyitoh IX Sumberejo Paiton Probolinggo sebagai berikut;

\section{Preparing The Program}

Kegiatan utama yang perlu dilakukan sebelum kegiatan belajar mengajar dilaksanakan maka hendaknya tenaga pendidik mempersiapkan semua kebutuhan bahan ajar yang akan disampaikan pada peserta didik. Selain bahan ajar atau materi maka tenaga pendidik juga harus mempersiapkan metode pembelajaran yang inovatif, memikat serta menyenangkan.

IF1 selaku kepala sekolah beliau mengatakan ada beberapa persiapan yang dilakukan oleh guru RA Masyitoh IX sebelum kegiatan proses belajar mengajar. Sebelum pembelajaran dilakukan jauh-jauh hari tenaga pendidik yang ada di RA Masyitoh IX sudah mempersiapkan bahan ajar yang sudah dirembuk pada rapat tahunan bersama seluruh komponen sekolah yakni kepala sekolah, wali kelas, guru pendamping dan pihak yayasan. Hasil rapat bersama memperoleh bahan ajar serta kegiatan PROTA, PROSEM, RPPM, RPPH yang dirangkum dalam kurikulum RA. Program perencanaan pramembaca (dokumentasi sekolah) diilustrasikan dengan gambar 2.

Dengan adanya prangkat pembelajaran yang sudah dibuat, maka guru mempunyai acuan atau panduan dalam mempersiapkan proses kegiatan belajar mengajar. Perangkat ini berupa prangkat tahuanan, semester, mingguan dan harian. Hal ini memudahkan guru RA Masyitoh IX dalam mengaplikasikan pembelajaran dengan cara meliat acuan dengan dikondidikan pada kebutuhan anak didik serta menyesuaikan dengan media yang akan digunakan dalam pembelajaran khusunya pada kegiatan pramembaca.

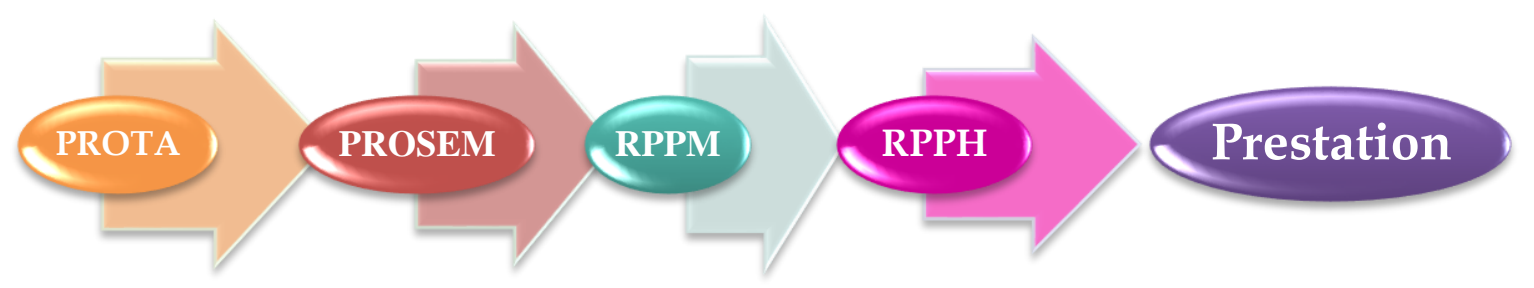

Gambar 2. Program Perencanaan Pramembaca (dokumentasi sekolah)

IF2 guru di RA Masyitoh IX mengatakan menyiapkan kegiatan belajar mengajar yang berpedoman pada RPPH yang ada, namun sekali-kali dikombinasi dengan kreatifitas serta strategi guru dalam memancing ketertarikan anak untuk lebih giat belajar, ketika kegiatan 
pramembaca dilaksanakan guru mempersiapkan kartu abjad, kartu penggabungan huruf dan kartu kosa kata, dimana kartu-kartu ini sudah dimodifikasi oleh guru-guru dengan berbagai macam kreasi seperti papan tempel, gantungan kartu dan boks kartu. Pada kegiatan ini guru mengkolaborasikan kegiatan yang ada dengan nyanyian dan tepuk sehingga anak lebih semangat dan antusias untuk mengikuti permainan.

Dengan persiapan yang dilakukan akan mempermudah tenaga pedidik dalam mengimplementasikan kegiatan pembelajaran terhadap anak didik, sebab semua program sudah terkonsep melalui pengemasan yang terstruktur serta sudah disesuaikan dengan kurikulum yang berlaku.

\section{Pre-Reading Card Presentation}

Dalam prestation atau penyajian pengenalan budaya pramembaca yang diterapkan pada anak usia dini, memiliki karakter yang menarik, kreatif, inovatif serta daya pikat energik yang ditunjukkan oleh guru sehingga anak lebih terpancing untuk mengikuti kegiatan pramembaca yang dipandu oleh guru.

IF3 sebagai guru RA Masyitoh IX menyampaikan bahwa implementasi kegiatan pramembaca dilakukan menggunakan dua metode, pertama metode klasikal yang diimplementasikan dalam satu ruangan dimana seluruh anak didik berkumpul untuk mengikuti permainan kartu pramembaca yang dipandu oleh satu guru dan guru yang lainnya menjadi pendamping. Kedua metode kelompok dimana satu orang guru memegang 7 anak pada masing-masing kelompok, jadi setiap guru mempunyai tanggung jawab terhadap 7 anak yang didampinginya. Kedua metode ini setiap hari dilakukan selang seling misal hari senin metode klasikal maka hari berikutnya dilakukan metode kelompok. Hal ini dilakukan untuk menghindari kejenuhan pada anak didik.

Implementasi permainan kartu angka dilakukan setiapa hari, kegiatan ini dilakukan sebelum kegiatan inti karena kegiatan budaya pramembaca dijadikan kegiatan pembiasaan di RA Masyitoh IX. Dengan pembiasaan yang dilakukan maka anak akan lebih mudah memahami kegiatan pramembaca tersebut. Adapun kegiatan pengenalan budaya pramembaca melalui metode permainan kartu sebagai berikut; Pertama, guru menyiapkan kartu angka dan posisi duduk anak didik. Kedua, guru menyapa anak didik mengucapkan salam dan menanyakan kabar dan absensi. Ketiga, bernyayi huruf alfabet bersama-sama dengan menunjukkan kartu sesuai pelafalan nyanyian. Keempat, guru memilih anak didik melalui absen atau acak untuk memilih kartu huruf dan menyebutkannya kemudian anak bisa menempelkan pada papan tempel atau kotak yang sudah disediakan. Kegiatan ini dilaksanakan secara bergantian terhadap semua anak didik sehingga semua anak didik bisa melaksanakan kegiatan tersebut.

1F2 presentation implementasi pembisaan pramembaca melalui permainan media kartu angka dilakukan dengan berbagai cara sesuai kreatifitas masing-masing guru, namun sebelum stimulasi kreatifitas guru kami biasanya menyebutkan huruf abjad secara bersamasama melalui nyanyian, kemudian main tebak angka yang dipilih sendiri oleh masing-masing anak, menempelkan huruf yang dipilih pada papan tempel dan menyebutkan hurufnya, menyebutkan huruf yang dipilih kemudian memasukkan pada kotak huruf.

IF1 mengatakan pada semester awal untuk kelompok A anak difokuskan pada pengenalan huruf, selanjutnya pada semester dua anak sudah dikenalkan pada gabungan huruf serta belajar menebali huruf samar. Sementara pada kelompok B untuk semester awal dikenalkan pada kata pendek melalui kartu huruf serta belajar menulis huruf dengan meniru pada kartu huruf dan selanjutnya pada semester berikutnya dikenalkan pada kata kompleks dua atau tiga kata yang diselingi dengan meniru tulisan kata sederhana. Pada media kartu huruf ada gambar yang mempermudah anak mengingat huruf maupun kata sehingga anak sangat antusias bermain kartu huruf dalam pengenalan pramembaca.

Presentation ini mampu memberikarikan stimulasi secara langsung terhadap anak didik dalam pengenalan pramembaca. Penggunaan kartu huruf yang diselingi dengan 
permainan kreativitas guru mampu mengundang daya tarik anak didik sehingga program pramembaca mampu terimplementasi dengan tepat sasaran serta mencapai target pembelajaran yang diharapkan. Kondisi permainan kartu huruf digambarkan pada gambar 3.
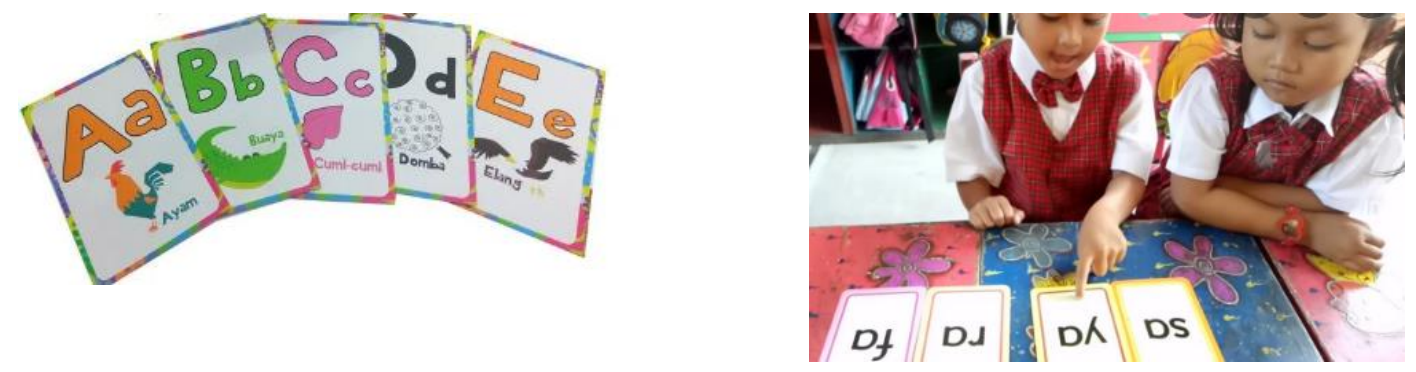

Gambar 3. Kondisi Permainan Kartu Huruf (Dokumentasi di lapangan)

\section{Asesment Pramembaca}

Asesment dilakukan sebagai bentuk observasi terhadap kegiatan yang sudah beberapa kali dilakukan. Dengan melakukan assessment maka tenaga pendidik mampu mengetahui sejauh mana tingkat pencapaian anak didik terhadap program yang sudah berjalan. Dari assessment ini juga bisa dilakukan langkah rencana berjenjang yang dilakukan untuk membuat perencanaan selanjutnya dalam upaya meningkatkan serta memperkuat program pengenalan budaya pramembaca pada anak didik.

Assessment dilakukan seobyektif dan sesistematik mungkin terhadap sebuah intervensi yang direncanakan, sedang berlangsung atau pun yang telah diselesaikan. Dari assessment tersebut dapat ditemukan pembandingan realisasi masukan (input), keluaran (output), dan hasil (outcome) terhadap rencana dan standar. Hasil assessment diperoleh selama kegiatan pemantauan berlangsung. Lebih dari itu, assessment juga menilai hasil atau produk yang telah dihasilkan dari suatu rangkaian program sebagai dasar mengambil keputusan tentang tingkat keberhasilan yang telah dicapai dan tindakan selanjutnya yang diperlukan.

IF2 menuturkan Asesment dilakukan satu bulan sekali yang dilakukan bersama dengan puncak tema, assessment ini akan mengetahui sejauh mana masing-masing peserta dalam memahami huruf, kata dan tulisan. Melalui assessment maka guru mampu mengevalusi program yang perlu dikurangi atau ditambah dalam upaya memperbaiki program yang sudah ada.

IF3 mengatakan hal-hal yang dilakukan penilaian dalam kegiatan pengenalan budaya pramembaca melalui permainan kartu yaitu; perkembangan anak dalam mengenal huruf, mengenal penggabungan huruf, mengenal kata dan keterampilan menulis. Waktu pelaksanaan penilaian sebenarnya setiap hari dilakukan dalam pencatatan anekdot namun yang lebih formal dialkukan setiap bulan ketika melakukan puncak tema.

Penelian ini berfokus pada perkembangan anak dalam pengenalan budaya pramembaca serta tingkat ketertarikan anak didik dalam melakukan permainan kartu pramembaca. Hasil dilapangan menunjukkan permainan kartu pramembaca mampu mengembangkan kemampuan membaca anak khusunya pada RA Masyitoh IX. Hasil tersebut didapatkan dalam wawancara dan observasi yang sudah penulis analisis sebelum memberikan pernyataan, bahwa perkembangan anak dalam memahami huruf, kata sederhana dan keterampilan menulis mulai menunjukkan perkembangan dengan meningkatnya pemahaman terhadap huruf dan kata serta keterampilan menulis huruf.

IF4 selaku wali murid juga memberikan penyataan bahwa anaknya mulai mampu membaca sederhana dan ketika dirumah juga suka bermain dengan permainan kartu huruf. Anaknya sangat antusias dan bersemangat ketika belajar dengan permainan kartu huruf sehingga peningkatan membacanya sangat signifikan dan memuaskan. 


\section{Kutipan dan Acuan}

Hal utama yang perlu dilakukan dalam upaya merancang suatu program atau pelatihan agar dapat berjalan efektif dengan melakukan analisa mengenai apa yang perlu dipersiapkan serta menganalisis semua kebutuhan melalui persiapan yang matang untuk mengetahui keadaan yang sebenarnnya (Basri \& Rusdiana, 2015).

Analisis persiapan dan perencanaan sangat diperlukan sebelum memulai pembelajaran agar guru lebih mudah dalam menyampaikan pelajaran. Persiapan mengajar merupakan salah satu bagian dari program pengajaran yang memuat satuan bahasan untuk disajikan dalam beberapa kali pertemuan atau tatap muka. Persiapan mengajar dapat digunakan sebagai dasar untuk menyusun rencana pembelajaran dan sekaligus sebagai acuan guru dalam melaksanakan kegiatan pembelajaran agar lebih terarah dan berjalan efisien dan efektif (Astuti, Muslim, \& Bramasta, 2020).

Perencanaan pembelajaran merupakan kegiatan memproyeksikan tindakan apa yang akan dilaksanakan dalam suatu pembelajaran yaitu dengan mengatur dan merespon komponen-komponen pembelajaran, sehingga arah kegiatan (tujuan), sisi kegiatan (materi), cara penyampaian kegiatan (metode dan teknik), serta bagaimana mengukurnya (evaluasi) menjadi jelas dan sistematis (Hanifah \& Amaliah, 2018; Zamroni \& Qatrunnada, 2021).

Pelaksanaan proses belajar mengajar kepada peserta didik merupakan beberapa cara dalam rangka mempersiapkan sumber daya manusia yang berkualitas dan dasar bagi pembentukan kepribadian yang utuh. Oleh karena itu dalam pemberian materi pembelajaran terdapat aspek-aspek yang harus dikembangkan dan ditanamkan dalam diri peserta didik, diantaranya aspek kognitif, bahasa, nilai agama, moral dan sosial. Pendidikan yang diberikan harus menyentuh pada aspek sosial mencakup tenggang rasa, kepedulian, saling menghargai, saling menghormati, mampu bekerjasama, empati dan sebagainya (Qasim \& Maskiah, 2016).

Dengan menganalis persiapan yang diperlukan dalam pembelajaran di RA Masyitoh IX maka semua unsur yang akan di implementasikan kepada anak didik dapat terpenuhi sesuai dengan kebutuhan anak didik. Tentunya hal ini dapat mempermudah dalam mengatur segala program yang akan dilakukan oleh sekolah dalam kaitannya dengan pengembangan kemampuan pramembaca yang dilakukan dalm penerapan budaya pramembaca melalui permainan kartu huruf.

Implementasi berasal dari bahasa Inggris yaitu to implement yang berarti mengimplementasikan. Implementasi penyediaan sarana dalam melakukan sesuatu yang menimbulkan sebab akibat. Implementasi dilakukan dalam mengaplikasikan sebuah rangkaian program terstruktur dan terencana dalam penerapan suatu program. Dalam penyampaian atau penyajian pembelajaran kepada anak harus bersifat menarik, energik, kreatif, dan inovatif sehingga anak berminat dalam pembelajaran yang disampaikan guru (Zamroni et al., 2021; Dakir et al., 2021).

Implementasi budaya pramembaca di RA Masyitoh IX dilakukan dalam mengenalkan cara mudah membaca dan menulis. Stimulasinya menggunakan metode pembelajaran permaianan kartu karena media ini dianggap mampu menungkatkan minat baca serta dapat mengkover kekurangan belajar tempo dulu yang dilakukan tanpa menggunakan media.

Melalui assessment dapat memberikan gambaran tentang apa yang terjadi dalam suatu program dan memastikan keterjangkauan elemen fisik dan struktural dari program yang direncanakan. Evaluasi ini juga disebut sebagai proses memperoleh data dan informasi yang diperlukan untuk menentukan derajat dan tingkat pembelajaran yang telah terjadi untuk membuat penilaian dan perbaikan yang diperlukan untuk memaksimalkan hasil.

Langkah terakhir yaitu penilainan atau asesment. Assessment dilakukan sebagai tindakan lanjutan dari pemantauan untuk melakukan pengukuran dan perbaikan dalam kegiatan yang diimplementasikan, seperti memadankan hasil-hasil kegiatan. Tujuan dari assessment sendiri yaitu agar perencanaan yang telah tersusun dapat mencapai tujuan yang ditetapkan dan dapat terselenggarakan. Hasil evaluasi dimaksudkan untuk merencanakan 
kembali, serta berfungsi sebagai administrasi dan manajemen yang terakhir (Baharun \& Wibowo, 2021).

Assessment sangat penting dalam mengembangkan kualitas Pendidikan. Sebab assessment mampu mendorong anak didik untuk lebih aktif dalam belajar terus menerus, mendorong guru untuk meningkatkan kualitas proses pembelajaran lebih lanjut, dan mendorong sekolah untuk meningkatkan fasilitas tambahan dan kualitas belajar siswa(Rozi \& Firdausiah, 2021). Untuk itu perlu SDM berkualitasi untuk membenahi dan meningkatkan manajemen Pendidikan anak usia dini, secara khusus terkait dengan pembelajaran Pendidikan anak usia dini yang meliputi proses perencanaa, pengorganisasian, pelaksanaan dan penilaian (Ita, 2018)

Melalui assessment yang dilakukan dalam rangka pengevaluasian system dapat memberikan arahan serta pembenahan selanjutnya untuk mengoptimalkan program yang sudah berjalan. Hal ini memungkinkan lembaga yang lebih maju serta dapat mengedepankan kebutuhan anak didik dalam upaya pembimbingan, pembinaan serta pengarahan pada tujuan pembelajaran yang lebih optimal.

\section{SIMPULAN}

Pengenalan budaya pramembaca perlu dilakukan serta direncanakan agar mampu memenuhi unsur-unsur pemecahan masalah pada anak usia dini khusunya pengenalan huruf dan kemampuan baca tulis. Dengan perantara media permainan kartu huruf RA Masyitoh IX mampu memberikan pemahaman kepada anak didik mengenai pengenalan pramembaca. Metode permainan kartu huruf dalam pengenalan pramembaca RA Masyitoh IX secara garis besar terlihat pada anak didik yang mulai menunjukkan perkembangan mengenal huruf, mampu membaca gabungan huruf, membaca kata sederhana dan menunjukkan keterampilan menulis.

\section{UCAPAN TERIMA KASIH}

Penulis mengucapkan terima kasih kepada semua pihak yang telah memberikan support dan dukungan dalam penyelesaian penelitian ini, baik secara langsung maupun tidak langsung. Ucapan terima kasih secara khusus penulis sampaikan kepada Rektor Universitas Nurul Jadid Paiton Probolinggo, Dekan Universitas Nurul Jadid Paiton Probolinggo serta Kaprodi PIAUD Universitas Nurul Jadid Paiton Probolinggo yang telah memberikan dukungan sehingga penelitian ini tuntas, baik secara langsung maupun tidak langsung.

\section{DAFTAR PUSTAKA}

Ahour, T., \& Haradasht, P. N. (2014). The Comparative Effect of Using Competitive and Cooperative Learning on the Reading Comprehension of Introvert and Extrovert EFL Learners. Advances in Language and Literary Studiesnces, 5(4), 207-214. https://doi.org/10.7575/aiac.alls.v.5n.4p.206

Akhmad Shunhaji, N. F. (2020). Efektivitas Alat Peraga Edukatif (APE) Balok Dalam Mengembangkan Kognitif Anak Usia Dini Akhmad. Block Caving - A Viable Alternative?, 2(2), 1-30. https:// doi.org/10.1016/j.solener.2019.02.027

Alfina, A., \& Anwar, R. N. (2020). Manajemen Sekolah Ramah Anak Paud Inklusi. Al-Tanzim: Jurnal Manajemen Pendidikan Islam, 4(1), 36-47. https://doi.org/10.33650/altanzim.v4i1.975

Aryani, E., Hasanah, A. U., \& Putra, H. D. (2021). Effect of Head Management Competence on Teacher Performance in SMA Nusantara Plus. Al-Tanzim: Jurnal Manajemen Pendidikan Islam, 5(2), 105-114. https:// doi.org/10.33650/al-tanzim.v5i2.2177

Asmonah, S. (2019). Meningkatkan kemampuan membaca permulaan menggunakan model direct instruction berbantuan media kartu kata bergambar. Jurnal Pendidikan Anak, 8(1), 29-37. https://doi.org/10.21831/jpa.v8i1.26682 
Astuti, D. P., Muslim, A., \& Bramasta, D. (2020). Analisis Persiapan Guru Dalam Pelaksanaan Pembelajaran Matematika Di Kelas Iv Sd Negeri Jambu 01. Jurnal Wahana Pendidikan, 7(2), 185-192. https://doi.org/10.25157/wa.v7i2.3676

Babuta, A. I., \& Rahmat, A. (2019). Peningkatan Kompetensi Pedagodik Guru melalui Pelaksanaan Supervisi Klinis dengan Teknik Kelompok. Al-Tanzim: Jurnal Manajemen Pendidikan Islam, 3(1), 1-28. https:// doi.org/10.33650/al-tanzim.v3i1.496

Baharun, H., \& Wibowo, A. (2021). Kepemimpinan Perempuan dalam Menciptakan Sekolah Ramah Anak. Quality, 9(1), 87-102. https://doi.org/10.21043/quality.v9i1.10109

Basri, H., \& Rusdiana. (2015). Manajemen Pendidikan dan Pelatihan.

Br, R., \& Asiya, D. (2021). Inclusive Education Management in the Development of Cognitive Intelligence of Children. Al-Ishlah: Jurnal Pendidikan, 13(2), 1057-1067. https://doi.org/10.35445/alishlah.v13i2.538

Dakir, D. (2017). Pengelolaan Budaya Inklusif Berbasis Nilai Belom Bahadat Pada Huma Betang dan Transformasi Sosial Masyarakat Dayak Kalimantan Tengah. Religió: Jurnal Studi Agama-Agama, 7(1), 28-54. https://doi.org/10.15642/religio.v7i1.707

Dakir, Muali, C., Zulfajri, \& Muali, C. (2021). Design Seamless Learning Environment in Higher Education with Mobile Device Design Seamless Learning Environment in Higher Education with Mobile Device. Journal of Physics: Conference Series 1899, 1899, 1-5. https://doi.org/10.1088/1742-6596/1899/1/012175

Eka, G. (2014). Peningkatan Kemampuan Membaca Awal Anak Melalui Permainan Kartu Gambar Di Taman Kanak-Kanak Negeri Pembina Agam. Jurnal Pesona PAUD, 1(1), 1-12.

Fardiah, F., Murwani, S., \& Dhieni, N. (2019). Meningkatkan Kemampuan Kognitif Anak Usia Dini melalui Pembelajaran Sains. Jurnal Obsesi : Jurnal Pendidikan Anak Usia Dini, 4(1), 133. https://doi.org/10.31004/obsesi.v4i1.254

Finori, F. D. (2019). Smart Techno Parenting : Alternatif Pendidikan Anak pada Era Tekhnologi Digital. Jurnal Tatsqif, 17(1), 52-69. https:// doi.org/10.20414/itq.v17i1.625

Fitriya, A. N. (2014). Peningkatan Kemampuan Membaca PRA-Membaca Kata Pada Anak Kelompok B Tk Puside Musi Melalui Media Permainan Kartu Huruf. Jurnal Pendidikan Anak, 3(2), 484-488. https://doi.org/10.21831/jpa.v3i2.11703

Hanifah, H., \& Amaliah, F. (2018). Manajemen Pembelajaran Bagi Anak Usia Dini dalam Meningkatkan Kualitas Pembelajaran di Pos PAUD Dahlia 15. Jurnal Comm-Edu, 1(3), 2429. https://doi.org/10.22460/comm-edu.v1i3.1102

Hidayati, R., YP, S., \& Artharina, F. P. (2019). Keefektifan Media Kartu Huruf terhadap Keterampilan Membaca Aksara Legena Siswa. Jurnal Penelitian Dan Pengembangan Pendidikan, 3(2), 112. $\quad$ https://doi.org/10.23887/jppp.v3i2.17388 https:// doi.org/10.23887/jppp.v3i2.17388

Iltiqoiyah, L. (2020). Manajemen Pembelajaran melalui Pendekatan BCCT dalam Meningkatkan Multiple intelligences Anak. Jurnal Obsesi : Jurnal Pendidikan Anak Usia Dini, 5(2), 13681381. https://doi.org/10.31004/obsesi.v5i2.781

Ita, E. (2018). Manajemen Pembelajaran Pendidikan Anak Usia Dini di TK Rutosoro Kecamatan Golewa Kabupaten Ngada Flores Nusa Tenggara Timur. Jurnal Dimensi Pendidikan Dan Pembelajaran, 6(1), 45-52.

Kristin, F. (2018). Meta-Analisis Pengaruh Model Pembelajaran Role Playing Terhadap Hasil Belajar Ips. Refleksi Edukatika: Jurnal Ilmiah Kependidikan, 8(2), 171-176. https:// doi.org/10.24176/re.v8i2.2356

Laila, A. N., \& Candraloka, O. R. (2019). Pemanfaatan Potensi Alam sebagai Alat Permainan Edukatif di PAUD Delima Jobokuto Jepara. E-Dimas: Jurnal Pengabdian Kepada Masyarakat, 10(1), 76. https://doi.org/10.26877/e-dimas.v10i1.2883

Lasaiba, D. (2016). Pola Pengembangan Model Pembelajaran Pendidikan Anak Usia Dini Di Lingkar Kampus Iain Ambon. Jurnal Fikratuna, 8(2), 79-104.

Milles, M. B., \& Huberman. (2014). Qualitative Data Analysis: A Methods Sourcebook. USA: Sage Publications.

Munawar, M. (2019). Supervisi Akademik: Mengurai Problematika Profesionalisme Guru di Sekolah. Al-Tanzim: Jurnal Manajemen Pendidikan Islam, 3(1), 135-155. https:// doi.org/10.33650/al-tanzim.v3i1.522 
Pertiwi, A. D. (2016). Study Deskriptif Proses Membaca Permulaan Anak Usia Dini. Jurnal Pendidikan Anak, 5(1), 759-764. https://doi.org/10.21831/jpa.v5i1.12372

Pusvitasari, R. (2021). Human Resource Management in Improving The Quality of Education. AlTanzim: Jurnal Manajemen Pendidikan Islam, 5(2), 125-135. https://doi.org/10.51276/edu.v2i2.132

Putri, N. P. A. A., \& Surya Abadi, I. B. G. (2021). Hubungan Disiplin Kerja dan Motivasi Kerja dengan Kinerja Guru. Managere: Indonesian Journal of Educational, 4(2), 75-84. https://doi.org/10.23887/jp2.v4i2.32763

Qasim, M., \& Maskiah. (2016). Perencanaan Pengajaran Dalam Kegiatan Pembelajaan. Jurnal Diskursus Islam, 4(3), 484-492.

Rahmat, P. S., \& Heryani, T. (2014). Pengaruh Media Kartu Kata Terhadap Kemampuan Membaca dan Penguasaan Kosakata. Jurnal Pendidikan Anak Usia Dini, 8(1), 101-110.

Retnaningrum, W. (2016). Peningkatan Perkembangan Kognitif Anak Usia Dini melalui Media Bermain Memancing. Jurnal Pendidikan Dan Pemberdayaan Masyarakat, 3(2), 207-218. https:// doi.org/10.21831/jppm.v3i2.11284

Rizqiyah, L. (2020). Melejitkan Ghiroh Belajar Santri Melalui Budaya Literasi di Pesantren. TADRIS: Jurnal Pendidikan Islam, 15(1), 108-117. https://doi.org/10.19105/tjpi.v15i1.3048

Rozi, F., \& Firdausiah, F. (2021). Implementation of Role-Playing Games in Overcoming Introverted Children. AL-ISHLAH: Jurnal Pendidikan, 13(2), 1394-1402. https://doi.org/10.35445/alishlah.v13i2.629

Rumidjan, Sumanto, \& Badawi, A. (2017). Pengembangan Media Kartu Kata Untuk Melatih Keterampilan Membaca Permulaan Pada Siswa Kelas 1 SD. Sekolah Dasar: Kajian Teori Dan Praktik Pendidikan, 26(1), 62-68. https://doi.org/10.17977/um009v26i12017p062

Selian, N. (2019). the Management of Pre School Towards Accreditation Standards. AL-ISHLAH: Jurnal Pendidikan, 11(2), 197. https://doi.org/10.35445/alishlah.v11i2.150

Simanjuntak, G. M., Widyana, R., \& Astuti, K. (2020). Pembelajaran Metode Multisensori Untuk Meningkatkan Kemampuan Pra-Membaca Pada Anak Usia Pra-Sekolah. Cakrawala Dini: Jurnal Pendidikan Anak Usia Dini, 11(1), 51-54. https://doi.org/10.17509/cd.v11i1.21082

Umiarso, \& Hidayati, N. (2022). Improving Children â€TM s Cognitive Intelligence Through Literacy Management. Jurnal Obsesi: Jurnal Pendidikan Anak Usia Dini, 6(3), 1588-1598. https://doi.org/10.31004/obsesi.v6i3.1817

Wahyudin, U. R., Winara, D., \& Permana, H. (2021). Teacher Professionalism Improvement Management: Study of Principal Leadership at SMA Al-Ittihad Karang Tengah Cianjur. AlTanzim: Jurnal Manajemen Pendidikan Islam, 5(2), 115-124. https://doi.org/10.33650/al-tanzim.v5i2.2222

Wildova, R., \& Kropackova, J. (2015). Early Childhood Pre-reading Literacy Development. Procedia - Social and Behavioral Sciences, 191(2), 878-883. https://doi.org/10.1016/j.sbspro.2015.04.418

Yunia, W. (2016). Improving Students' Speaking Skill By Using Stad (Student Teams Achievement Divisions). Al-Ishlah: Jurnal Pendidikan, 8(1), 136-153.

Zamroni, \& Qatrunnada, W. (2021). Utilization of Digital Applications in Learning Assessment Utilization of Digital Applications in Learning Assessment. Journal of Physics: Conference Series, 1899, 1-5. https://doi.org/10.1088/1742-6596/1899/1/012156

Zamroni, Amir, \& Saleha, L. (2021). Pengelolaan APE Berbahan Limbah untuk Meningkatkan Kecerdasan Kognitif Anak. Jurnal Obsesi: Jurnal Pendidikan Anak Usia Dini, 5(2), 13821395. https://doi.org/10.31004/obsesi.v5i2.763 